\title{
Gothic Reality: A Study of Emily Bronte's Wuthering Heights
}

\author{
Roumaissa Moussaoui \\ Department of English, University of Ali Lounici ( Blida 2) \\ Blida, Algeria \\ Email: roumaissamoussaoui@yahoo.fr
}

Received: 5/18/2021 Accepted: 7/31/2021 Published:8/25/2021

\begin{abstract}
Emily Bronte's novel, Wuthering Heights, is a gothic novel with an innovative stance. Gothic elements permeate the story, but it is not a gothic novel in the traditional sense of the word. The fantastic tales so popular in the eighteenth century alienated the reader by creating phantasmagorical worlds. Emily Bronte, however, grounded her gothic world firmly in reality. Through an analytical approach, the author aims to show, in this article, how Emily Bronte reversed gothic conventions to create a gothic reality whose message is still relevant today. The author will show that her use of the gothic mode was an attempt to capture the real essence of life, anticipating the metaphysical theories of D. H. Lawrence, who wrote at the end of the nineteenth century. By highlighting her innate understanding of human nature, this article will focus on her affinity with Lawrence and the celebration of man's powerful primal instincts. This article hinges on the premise that she deplored the mechanical restrictions of the society in which she lived. The author aims to show that her Gothicism is, paradoxically, synonymous with a search for life.
\end{abstract}

Keywords: Wuthering Heights, being, Lawrence's metaphysics, The essence of life, Gothicism, gothic reality, Yorkshire moors

Cite as: Moussaoui, R. (2021). Gothic Reality: A Study of Emily Bronte's Wuthering Heights. Arab World English Journal for Translation \& Literary Studies 5 (3) 40-54.

DOI: http://dx.doi.org/10.24093/awejtls/vol5no3.4 


\section{Introduction}

While the Eighteen century stressed the supreme value of reason, it could also be called the age of Gothic fiction. Many writers, disill usioned with the constraints of the Renaissance era, were attracted to the gothic genre, which became one of the most popular forms of imaginative expression. In 1764, Horace Walpole wrote the first gothic novel, The Castle of Otranto . Other examples followed, including The Mysteries of Udolpho by Ann Radcliffe in 1794, The Monk; A Romance by Matthew Gregory Lewis in 1796, and The Fall of the House of Usher by Edgar Allan Poe in 1839.

Traditional gothic fiction was based on the myths and legends of folklore and conjured up magical worlds populated by monsters, ghosts, and demons. The Augustan age, on the other hand, a period of neoclassical revival, tended to repress the emotions, deriding the mysterious forces of the personality, which were thought of as barbaric and associated, therefore, with the Middle Ages. The contrast between the two genres was clear. The classical was ordered and pure, establishing clear rules and limitations. The Gothic was gloomy and sublime, creating a world of chaos and exaggeration. The scholars of the Renaissance era derided the fantastical tales of folklore, upholding reason as the only means of acceptable expression. However, later in the century, the skepticism attached to the value of reason led to a gothic revival that threatened eighteenth century rationality and morality. Imagination knew no bounds and the fantastic, the grotesque, the savage, and the mysterious became significant elements in the plot whose primary purpose was to entertain, stirring up emotions without restraint by reason.

Gothic fiction was synonymous with an excess of imagination. The dark, mysterious worlds conjured up in the plot seemed completely divorced from reality. As a result, most of the fiction written in this genre was not taken seriously and any moral message was, at best, misunderstood or, at worst, ignored. The eighteenth century novelist had the choice of writing either a fantastical tale, with the sole purpose to entertain, or a satirical text, based on the neoclassical principles of common sense, moderation and reason. A gothic novel celebrated an excess of feeling, a neoclassical text, an excess of reason.Through an analytical study of Wuthering Heights, the author of this article aims to show how Emily Bronte resolved this dichotomy by inversing gothic tradition to create a powerful tale of romance so firmly grounded in reality that its message is still relevant today. By focusing on a Lawrentian interpretation, this article will show how Bronte anticipated Lawrence's metaphysics of being, infusing her gothic elements with positive connotations and a promise of life.This research will further the premise that if Bronte had lived, she would have developed her ideas into a full-blown philosophy, rivaling those of some of the most powerful writers of the twentieth century.

This article is divided into four sections. The first section describes how Emily Bronte sets her gothic romance in a realistic setting, drawing on her own childhood experiences, thus enhancing the credibility of her text. The second tries to show how the author uses meteorological elements to reflect emotions and show the uncontrollable nature of human feelings. The third section deals with characters. It argues that Bronte moved away from the stereotypical characters of gothic fiction, describing them realistically and making her reader sympathise with them. The 
fourth section, with its emphasis on being, puts forward the premise that, through her innate understanding of human nature, she anticipates the metaphysics of D. H. Lawrence.

\section{Literature Review:}

As a nineteen century writer, Emily Bronte was attracted to the gothic mode and the freedom it allowed her to express herself. Her novel, Wuthering Heights, is impregnated with gothic elements. The theme has been discussed endlessly by critics who unanimously agree that the author used the genre to explore her creativity. Syndy McMillen Conger,in 1994, for example, links Bronte's Gothicism to the demands of the feminist movement, portraying a strong and independent woman struggling against the demands of a repressed, patriarchal society. Hajuan $\mathrm{Fu}$ (2013) focus on Bronte's literary thought, stating that she "not only inherits gothic interpretation tradition but also develops it". In her article, Yukari Oda (2010), compares the central female characters of Wuthering Heights to traditional gothic heroines. Her analysis shows how Bronte manipulated the gothic form to portray her own unique message. Weirong Qiao (2019) states that "Emily Bronte bandoned the main stream of English literature ... and became world famous with the gloomy and gostly gothic novel which is legendry in its own writing" (p. 1). The scholar recognizes Bronte's "depiction of the darkness in humanity" through her use of the gothic elements. In his thesis Mohammed Altayeb Rabih Musa (2016), links Bronte's use of gothic element to "the suppressed feelings of the main characters" (p. 3). By focusing on a psychological approach, the author relates the dark side of human nature" to the issues of childhood violence, social problems and destructive relationships.

This article takes a similar stance, and examines Bronte's innovative use of the gothic to show how she created a gothic reality which incorporated a message so vital and so real that it is still relevant today. This research will forward the premise that Bronte, through her innate understanding of human nature, anticipated the metaphysical doctrine promulgated by D.H. Lawrence at the beginning of the twentieth century.

Emily Bronte threw off the constraints of reason and rejected the dogma of neoclassicism, allowing her imagination free reign to explore human emotions and feelings. However, her Gothicism is very different from the fantastic tales so common in the eighteenth century, which conjured up fantasy worlds inhabited by monsters, ghosts and demons. She used the genre innovatively, grounding her story firmly in reality, to create a world of passion and mystery whose message is still relevant today.

Eighteenth century gothic novels were a veiled criticism of the society of the time. Divorcing themselves from the rational clarity of the neoclassical age, gothic writers created a fantasy world to covertly criticize social issues of the day. The fact that these gothic writers felt the need to submerge their message by creating phantasmagorical worlds is a stark criticism of the society of the time. Furthermore, most of them wrote their novels using a pseudonym. Horace Walpole, a respected and enlightened member of parliament, for example, not only wrote his novel under a false name, but also pretended that it was the translation of a medieval manuscript, further distancing himself from his work. Although he ownrd up to his "disguise" (Clery, 2010, p.1) in the second edition, proclaiming it to be a mechanism of self-preservation in case of unfavourable 
reception, it could be argued, here, that this instinct to distance himself from his work, was based on the fear that his social message, about Britain's patriarchal society, would be deciphered leaving him vulnerable to the charge of seditious libel. At the time, such a charge brought with it imprisonment, social ruin, and dishonour.

The term gothic comes from the name of a Germanic tribe which originated in southern Scandinavia during the second century AD. The Goths were a forceful and barbaric tribe, who, together with the other Germanic tribes in the area, successfully brought down the Roman Empire. For many historians, there followed a dark period in the history of the British nation. An ordered and structured civilization had been destroyed by an uncivilized and barbaric force and they mourned the chaos that ensued. The connotations for the eighteenth century were clear. To allow a gothic revival to impinge on the cherished values of reason, epitomized by the Renaissance era, was seen by many as an act of sedition.

\section{Methods}

By focusing on an analytical approach, this article aims to explore Emily Bronte's use of the gothic genre to show how, through her innovative technique, she succeeds in creating a gothic reality whose message is relevant today. It hinges on the premise that she reversed gothic conventions, grounding her elements firmly in reality, making her story believable, and nurturing empathy in her readers. It aims to show how successful she was in conjuring up an atmosphere where gothic reality breathes, where fantasy becomes reality, and where life transcends the traditional gothic atmosphere of gloom. By making a direct comparison with the metaphysics of D. H. Lawrence, this article forwards the premise that Emily Bronte, through her innate understanding of human nature recognised the primal instinct of the human personality, criticizing the nineteenth society for its inability to assimilate them into its social fabric.

\section{The Setting}

The most important element in a Gothic novel is the setting. Many Gothic novels are set in Northern Europe, in the distant past, usually in the Middle Ages. Most of the action takes place in castles, monasteries, or abbeys, which are set in remote locations, far from civilization. Represented by a specific architecture, composed of a labyrinth of corridors, hidden passages, turreted towers, dark dungeons and damp cellars, such settings were alien to the everyday experience of the ordinary reader. Their sole purpose was to create an atmosphere of suspense and terror.

Most $18^{\text {th }}$ century gothic novels belong to the realm of imagination. They created fantasy worlds far removed from reality whose only purpose was seemingly to entertain. The supernatural elements of their phantasmagorical settings served to annihilate any empathy the reader might have had with the protagonists. In fact, all these conventions coupled with the anonymity of the writer, were deliberately contrived to divorce the reader from reality.

Gothic novels were some of the first literary forms of social critique. Homer (2010) states that "It is now generally acknowledged that, despite having plots and characters that might be larger than life, gothic fiction bears a fascinating and complex relation to material, cultural and political reality"(p. 1). By creating their phantasmagorical worlds, writers of gothic fiction were 
able to conceal unpopular but controversial ideas related to the issues of the time. In the $18^{\text {th }}$ century, to speak out against the government was considered to be seditious. Thus, the medieval setting and the foreboding atmosphere were evoked to conceal the author's socio-political message. Although Horace Walpole's novel The Castle of Otranto is a complete flight of fancy, it covertly attacks the patriarchal society of the time, especially male inheritance. The castle, with its labyrinth of corridors, secret passageways, and obscure cloisters became a symbol of a claustrophobic society, dominated by men, and governed by a rigorous class system, from which there was no escape. The long labyrinth of corridors within the gloomy castle is a powerful image. Conventional society was a prison where rights were denied and desires thwarted in a barbaric system hidden by a veneer of civilization.

By the time Emily Bronte wrote Wuthering Heights in the middle of the $19^{\text {th }}$ century, society had become more liberal towards artistic expression, and reputation was no longer synonymous with royal favour. This prompted her to explore the gothic mode from a realistic stance. Although she wrote under the pseudonym of Ellis Bell, in accordance with gothic convention, she set her story in the wild and eerie Yorkshire moors, native to her childhood. She had no need to draw on her imagination to create her gothic world. She was, to quote the words of her sister Charlotte, "a native and nursling of the moors" (Brontë, 2009, p. 14). Like traditional gothic novels, their isolation and remoteness are emphasized throughout the novel but their description owes nothing to the imagination. In the editor's preface to the new edition of the novel, Charlotte Bronte, in the following quote emphasises this "With regard to the rusticity of Wuthering Heights, I admit the charge, for I feel the quality. It is rustic all through; It is moorish, and wild, and knotty as a root of heath. Nor was it natural that it should be otherwise" (p. 14). The words "I feel the quality" in the above quotation, are pivotal to an understanding of the author's aim in writing her novel. Far from divorcing her readers from her narrative, as the gothic genre formerly dictated, she used her creativity to instil in them the "horror of great darkness". By setting her novel in a realistic setting, she hoped her readers would feel the actual desolation, the real isolation, and live the story with her. Her sister, Charlotte once again, attests to the power of the novel - "in its storm-heated and electrical atmosphere, we seem at times to breathe lightening" (p. 27). The word "breathe", with all its connotations of life and vitality, is poignant in its imagery. The conventional gothic world was dangerous and destructive, sapping the life force from all that dared to trespass there. Paradoxically, the gothic world of Emily Bronte breathes life, is full of vitality, and is responsible for creating one of the greatest passions that English literature has ever known.

In her novel Wuthering heights, Emily Bronte creates two asymmetrical worlds: the conventional Thrushcross Grange, representing refinement and civilization, and the gothic Wuthering Heights representing the unrestrained savagery of the moors. It depicts a woman who is torn between her need for social standing and her desire to fulfil her illicit relationship with her childhood friend. Bronte reverses the literary convention, which depicts the gothic as menacing and destructive in its fantasy to create a gothic world that is real, vital and innovative. Her heroine, Catherine was aware of the force of the Moors. She felt that it had the ability to relieve her physical and mental suffering. In her last illness, she begged Ellen to open the window overlooking the moors so that she would be able to "breathe". Paradoxically, in the midst of high society, she was 
tortured by loneliness and isolation. She felt stifled by conventions and only the moors could offer her life.

In most eighteenth century gothic novels, the setting emphasized the themes of imprisonment and entrapment. The gothic world was dark and gloomy, full of confined spaces dank, dungeons, ${ }^{2}$ and damp cellars. A favorite device of the gothic includes confining a person in a dark cell or a cloister, clamping him in irons, or shackling to the floor. This reinforces the claustrophobic atmosphere and forces the reader to understand that there is really no escape. In her novel Wuthering Heights, Emily Bronte inverses this idea. Her gothic world -the wild and savage Yorkshire moors, are to both Catherine and Heathcliff, a place of freedom and escape. During her last illness, Catherine longs for the freedom of her childhood, always associated in her mind with her wanderings on the Moors "I wish I were a girl again half savage, hardy and free" (Brontë, 2009, p. 116). Both Heathcliff and Catherine have an affinity with the Moors. The wildness of the elements, the ruggedness of the landscape, and the severity of its isolation, not only served to nurture their unbridled passion, but also came to represent, for both of them, a place of refuge and escape.

After the death of Mr. Earnshaw, Catherine's father, their home becomes a "prison" of persecution and violence, and the children's only source of comfort was to find refuge on the Moors. Hindley, taking their father's place, becomes a tyrant and orders "Heathcliff a flogging, and Catherine a fast from dinner or supper. But it was one of their chief amusement to run away to the moors in the morning and remain there all day" (Brontë, 2009, p. 52). The ungrammatical use of the conjunction "but" at the beginning of the sentence in the above quote under,lines the incongruity that these young children were able to find "amusements" in a wild and savage environment, instead of in the security of their own home. The Moors became their home, nurturing their relationship and providing them an escape from the tyranny of both Hindley and Joseph.

As we have seen in this section, Emily Bronte's gothic setting is firmly anchored in reality. She draws on her childhood memories to create a gothic atmosphere of electrifying savagery, forcing the reader to "breathe lightening" and live the story with her. The reversal of gothic convention, from the setting of a fantasy world to the realistic backdrop of the eerie Yorkshire Moors, enhances the credibility of the Bronte's romance and encourages the readers empathy with her characters.

\section{The Weather}

Traditionally, the weather depicted in Gothic fiction is cold, dark and stormy. It was used essentially to increase a sense of foreboding and help establish an atmosphere of terror and suspense. Fog, for example, permeates Robert Louis Stevenson's novel, The Strange Case of Dr. Jekyl and Mr. Hyde, to obscure objects, heighten the mystery and conceal the truth. Meteorological elements are also used liberally to reinforce the themes of entrapment and helplessness. From the perspective of the plot, they are used to trap characters and restrict their freedom. Snowstorms are used to hamper movement, fallen trees block roads and bridges are washed away, eliminating the character's only way of escape. 
Emily Bronte was also aware of the importance of weather to cultivate her gothic atmosphere. In fact, at the beginning of the novel, it is a violent snowstorm that prevents Lockwood from returning home, thus allowing the story to unravel. However, for Bronte, the weather was so much more than a mere tool to help advance her plot. Violent weather, usually in the form of storms, signifies upheaval in the lives of her characters. On the evening of Heathcliff's disappearance, for example, the violent storm marks a turning point in both the lives of Heathcliff and Catherine. In the phrase "The storm came rattling over the Heights in full fury" (Brontë, 2009, p. 83). The definite article "the" underlines its symbolic importance. The lives of the two young people would never be the same again, and the violence of the storm-its "full fury"-reflects the intensity of their emotions. The destruction of the chimney is poignant in its imagery. The chimney was the focal point of any Victorian household, nurturing feelings of belonging and security. The family would meet around an open fire to discuss the events of their day while the children played close by. Its destruction, then, in the novel, symbolizes the dramatic change in the young people's lives. They have lost ,forever, both their material, and their spiritual, home. Catherine is aware of this and she refuses to take shelter. She is "thoroughly drenched for her obstinacy in refusing to take shelter" (p. 83). She realizes now, that with Heathcliff gone, there is no longer any shelter.

There are many passages throughout Wuthering Heights where the weather appears to contradict the season. Emily Bronte uses the irrational nature of the weather to symbolize the uncontrollable nature of human feeling. The storm at Heathcliff's disappearance is one such example. In the phrase "It was a very dark evening for summer" (Brontë, 2009, p. 83), the use of the preposition "for" suggests that this kind of storm is unlikely to occur in this season. The image is powerful and reflects the turmoil that Heathcliff is feeling. He has experienced a summer of love with Catherine but his dreams have suddenly been thwarted by the knowledge that she is to marry Linton. In a Similar way, the weather suddenly changed when Catherine died. Ellen Dean recounts "That Friday made the last of our fine days for a month. In the evening, the weather broke; the wind shifted from the south to the north-east, and brought rain first, and then sleet and snow" (Axelrod, 1999, p. 55). The long stretch of bad weather symbolizes Heathcliff's insurmountable grief and the coldness of his feelings now that Cathy has died. He, himself, remembers that on "the day she was buried there came a fall of snow....It blew bleak as winter - all around was solitary" (Brontë, 2009, p. 156). Once again, the preposition "as" emphasizes the incongruity of snow during this season. It not only symbolizes the intensity of Heathcliff's feelings, at the loss of his beloved, but also conveys the unexpected nature of her death. It begs the question why a person so vital and so young should die so suddenly. What is this mysterious force that has ultimately destroyed her?

Traditionally, in Gothic literature, the weather is violent and destructive, fuelling the feelings of foreboding and terror. However, Emily Bronte, through her innovative technique, shows even the most violent weather as a positive force. In Wuthering Heights, the rain can be seen to quench and to purify. On the night of Heathcliff's disappearance, Catherine stands "bonnetless and shaw-less to catch as much water as she could" (Brontë, 2009, p. 83). The auxiliary verb "could" emphasizes that her refusal to take shelter is deliberate. Her desire for Heathcliff"s return is so strong that, only by drenching herself in the rain, can her desire really be quenched. Similarly, when Heathcliff dies at the end of the novel rain is seen as a vital force .Ellen Dean 
remembers that "The following evening was very wet; indeed it poured down till day-dawn; and as I took my morning walk round the house, I observed the master's window swinging open, and the rain driving straight in...it poured down till day-dawn" (p. 277).

The fact that his hand "rested on the sill" $p$ indicates that he, himself, had opened the window. Like Catherine, he deliberately sought the quenching power of the rain to satisfy his ache to be with Catherine once again. Unlike Catherine, he succeeded in his quest .His "life-like gaze of exultation" (Brontë, 2009, p. 277) attests to his success. Rain has not only quenched his desire but it has purged him of his demons. In the phrase "but his face and throat were washed with rain", (p. 277) the verb "washed" emphasizes the idea of purification. The rainwater has cleansed him of his inner anger, replacing it with a spiritual calm as he is finally reunited with the woman he loved.

In her portrayal of the weather, Emily Bronte makes full use of metrological elements to illustrate the state of mind of her protagonists. She emphasizes incongruity in the weather to symbolize heightened emotional tension and the uncontrollable nature of human feelings. In her novel, storms reflect inner turmoil; snow portrays the glacial grip of grief, and rain becomes the outward manifestation of internal despair. In Bronte's gothic reality, however, the weather is not only destructive. The rain, especially; is seen as a purging force, a quenching that aims to extinguish the aching fire within her protagonist souls.

\section{Characters}

Traditionally, the male and female protagonists in gothic literature are stereotypes which means that their characters never change throughout the novel. Horace Walpole set the precedent with his portrayal of Isabella as a pure and defenseless victim, abused and tortured by a tyrannical and vicious male. As the gothic genre evolved, more stereotypes appeared, ranging from the dutiful wife and mother to the madwoman and the permissive femme fatale. Similarly, two types of male protagonists can be found representing the two extremes of human nature: the dark and powerful villain, whose role is to persecute and subdue, and the fair and handsome hero, who generally rescues the heroine from the clutches of her capturer. They are all stock characters, recognisable by everyone, and used by the author to represent the forces of good and evil. In fact, Yukari Oda (2010) sums up the simplified nature of gothic fiction:

Gothic characters can usually be divided into two types, the good and the evil.... Gothic heroines belong almost invariably to the good, and wish to escape from the evil to the other, without experiencing any difficulty in choosing between them; their ways of thinking are conventional, and they do not consider the possibility of any middle ground between the two extremes" (p. 27)

It is clear, from the above quotation, that character development is not a major consideration of the gothic. Stock characters, both male and female, become an integral part of the plot, depicting the power struggle between the forces of good, on the one hand, and the forces of evil, on the other. Furthermore, as Yukari Oda emphasizes, such a conventional theme results in a conventional outcome: good usually triumphs over evil and traditional order is restored. 
The power struggle, which is the central element of the plot, is a fictional representation of the conflicts of the actual world. This conflict centres on the struggle between the genders and the female quest for recognition and identity in a predominately patriarchal society. Avril Horner states that early gothic novels "reflect anxieties more obviously connected with women's experience of disempowerment at this time" (Horner, 2010, p. 2). As the word "disempowerment" signifies, the conflict is external. It epitomizes the physical challenges that women face in a hostile society. Gothic literature simplifies the equation. In the eighteenth century, at a time when gothic literature reached its peak, the disparities between the sexes was so great that women sought only physical recognition of their place in society. Psychological development was not an issue; hence, archetypes served the authors' purpose more effectively than any rounded character would have done. Furthermore, stereotypes more accurately reflected the society of the time, which ignored not only women's civil rights but also their feelings and personal fulfilment.

Conflict is one of the major themes of Wuthering Heights, but Emily Bronte shifts the power struggle from one of gender to one of class. The stock situation, a damsel for who two opposing forces fight, remains a central element of the plot but the author, uses the conflict that ensues, in an original and innovative way. S. Conger states;

Gothic heroines were traditionally placed in a conflict situation between a dark seducer and a fair lover, but theirs was an external conflict, they never felt - admitted that they felt - a pull in two directions. Catherine is the first important exception to that pattern, for she internalizes her conflict completely. She is not simply placed between two lovers; she feels divided between two lovers. (Conger, 1983, p. 26)

The emphasis is on the verb "feel". Emily Bronte breaks with gothic tradition to create a complex heroine, more realistically portrayed, and through her use of evocative language, she makes her heroine "feel", and forces the reader to "feel" empathy with her.

Unlike the gothic heroine, whose fate was decided by outside forces, Catherine Earnshaw is responsible for her own destiny. She consciously chooses to marry Linton, favouring social status over her illicit relationship with Heathcliff. Emily Bronte portrays her as a strong-minded and wilful woman, far removed from the wilting heroines of traditional gothic fiction. She actively participates in her life decisions, and through her egocentricity, believes she can manipulate any situation to meet her own demands. Her declaration to Nelly "If I marry Linton, I can aid Heathcliff to rise", (Brontë, 2009, p. 81) underlines her naive belief that she can control both men and make them bow to her wishes. In her innocence, she fails to grasp that neither man will be content with half-measures. Her efforts to reconcile the two consume her, torture Heathcliff, and and finally destroy her.

The traditional gothic heroine is never portrayed as equal to her male counterpart and she is almost always afraid of him. In Wuthering Heights, Emily Bronte inverses this convention. Catherine is never afraid of the brooding Heathcliff, and she sees herself, as not only equal to him, but as one with him. She once tells Nelly: "Ellen, I am Heathcliff” (Brontë, 2009, p. 71). In fact, in a subtle shift in gender politics, Emily Bronte's heroine becomes the rapacious predator, set to 
destroy not only the two men in her life but her own self as well. Nelly describes her in particularly ghoulish and vivid terms - "Her present countenance had a wild vindictiveness in its white cheek, and a bloodless lip and scintillating eye" (Brontë, 2009, p. 148). This description not only presages her impending death but also anticipates the life-sucking nature of her love. Although her "white cheek" and "bloodless lip" indicate that her body is dying, her "scintillating eye" illustrates that her soul is very much alive.

Traditionally, in gothic fiction, the villainous male subdues or, ultimately destroys, the female. In the portrayal of Catherine Earnshaw, however, the roles are reversed. Although, she declares to Heathcliff that "You and Edgar have broken my heart, Heathcliff! (...) You have killed me and thriven on it, I think" (Brontë, 2009, p. 171) through her death, she ultimately destroys both men. Her husband, Edgar, is transformed into "a complete hermit", retires from society and becomes a shadow of his former self. His grief is assuaged only when he he transfers his affection for Catherine onto her daughter, Cathy, and he slowly come to life.

On the other hand, her death completely annihilates Heathcliff. Her accusation to him, that he had thrived on her misery, is completely reversed. In death, her love for him has become "vampiric". Heathcliff describes, in macabre detail, how, on Edgar's death, he persuaded the sexton to clear the soil from Cathy's coffin so he could lift the lid. The phrase "(...) I saw her face again (...) it was hers yet" (Brontë, 2009, p. 241) is graphic in its symbolism. In death, Cathy has fed on Heathcliff's love and devotion to remain essentially unchanged. The deterioration in Heathcliff is apparent, however, especially at the end of his life. Ellen describes him as "unnatural" with "a bloodless hue" (p. 241) and a "ghostly paleness" (p. 241). Through the use of such adjectives, Emily Bronte makes a direct parallel to Catherine on her death bed. Their love has turned full circle. Heathcliff's vengeful actions, in her life-time, destroyed her. Now, in her death, she has destroyed him.

In her portrayal of her characters, Emily Bronte, once again, reversed gothic tradition. She deliberately broke away from the stereotypic characters of the gothic mode to create realistic protagonists who almost live through the pages of her book, emphasizing her literary message, and forcing the reader to live with them. The story is a celebration of life, necessitating well-developed characters, which give veracity to her gothic reality, underlining her universal message.

\section{Being}

In the $18^{\text {th }}$ century, the gothic mode was used to counteract the restraints of the age of reason, giving the imagination free rein to create phantasmagorical worlds, populated by ghosts, vampires and skeletons. In her novel, Wuthering Heights, Bronte grounds her gothic elements firmly in reality to explore the complex nuances of the human personality. Through her portrayal of Catherine, she depicts a woman torn between her need for social standing and her desire to fulfil her illicit relationship with the brooding and wayward Heathcliff. The subsequent conflict torments her, consumes her and finally, destroys her.

It can be argued, here, that such a conflict reflected the reality of many women in the middle of the 19th century. The advent of the industrial revolution, which undermined the rigorous class system that had dogged social interactions since the Middle Ages, together with the social and 
political thinking of Jeremy Bentham, and later, John Stuart Mill, changed the fabric of British society. Women began to question their social status and, for the first time, the concept of their subservience to men. They started to rebel against a society which demanded absolute obedience to antiquated rules which could no longer ensure "the greatest happiness of the greatest number".

Catherine Earnshaw's conflict, then, is firmly grounded in reality. In fact, Charlotte Bronte, in the preface to the second edition of the novel, in an attempt to defend her sister against the negative criticism of an age of rational thinking, clearly indicates that her sister drew on her own personal knowledge of the "peasantry amongst whom she lived (...), And yet she knew them; knew their ways, their language, their family histories; she could hear of them with interest, and talk of them with detail, minute graphic and accurate" (Brontë, C., Brontë, E., \& Brontë, A., p. 720) The conjunction, "yet", at the beginning of the sentence, seems to imply so much more than mere knowledge of them. It indicates an empathy with them: an empathy based on shared emotions and frustrations.

It can be said, then, that Catherine's conflict is a reflection of her own. Emily Bronte was a woman of her time, fighting for recognition in an intellectual world, exclusively dominated by men. She was a woman torn between what society expected of her, and her own, personal need to express herself. As a woman writer, she had to fight against the patriarchal values so succinctly expressed by Disraeli in 1812 - "Of all the sorrows in which the female character may participate, there are few more affecting than that of an Authoress" (Disraeli, I., \& Disraeli, B., 1868, p. 297). In the world of literature, women, at that time, were not taken seriously and Emily Bronte had a real fight on her hands. No wonder, then, that she was attracted to the gothic mode: a genre whose subterfuge not only permitted her to write under a pseudonym, but also allowed her to explore the deep-set frustrations of the human mind.

Emily Bronte's character study in Wuthering Heights anticipates interest in the human psyche. In a critical commentary on Wuthering Heights, Margaret Willy recognizes Bronte's innovation and states that her technique in the portrayal of her characters is "remarkably modern". Her innate understanding of human nature anticipated Sigmund Freud's division of the personality, and numerous studies have been made giving a Freudian interpretation of the novel. Gold (1985), for example sees in "the symbiosis of Catherine, Heathcliff and Linton the relationship of Freud's id, ego and superego" (pp. 3). Similarly, Homans sees in Bronte's description of nature, elements of repression, associated with the theories of Freud. According to Homans such descriptions reflect the raw, negatively charged emotions associated with the id. These critics all associate the gothic elements of the novel with the "cesspools of hidden desires"; the dark and dangerous instincts lurking in the subconscious.

In recent years, too much emphasis has been given to a Freudian interpretation of the novel. Many critics interpret the gothic elements of the novel as symbols of the repressed, irrational side of the human personality. However, in the next section of this article, the author aims to show that Emily Bronte turned to the gothic genre in an attempt to capture the real essence of life, to make both herself, and her readers, "breathe lightening", through the pages of her book. In fact, the aim is to go beyond a Freudian interpretation, with its negative connotations of repression and the 
denial of life, to show how Emily Bronte used her literary technique to anticipate the metaphysical philosophy of one of the greatest writers of the 20th century: that of D.H. Lawrence

In 1828, when writing his novel, Lady Chatterley's Lover, Lawrence said - "What liars poets and everybody were! They made one think they wanted sentiment. When what one supremely wanted was this piercing, consuming rather awful sensuality" (Lawrence, Squires, 1994, p. 247). Over 70 years before him, in writing Wuthering Heights, Emily Bronte covertly voiced a similar message. Her novel was a stark rejection of the sentimentalism that had become so popular, in both poetry and prose, at the end of the $18^{\text {th }}$ century. She repudiated the "fine feelings" of the age, cultivated, in art, to show strength of character and experience. Hampered by both her sex, and the conventions of the time, Gothicism was the only tool she possessed to explore the raw and irrational power of human emotions. Through her innovative technique, she makes her gothic real in order to show love as a "wild rose-briar" (Brontë \& Hatfield, 1995, p. 140). This imagery is poignant and is central to an understanding of the novel. The relationship between Catherine and Heathcliff is wild and untamed. It is a thing that can cause so much joy, and, paradoxically, so much pain.

Emily Bronte's untimely death meant that she had very little chance to develop a full-blown philosophy. However, her innate understanding of human nature, as revealed in her novel, Wuthering Heights, anticipated Lawrence's metaphysical theory. If she had lived to see the advent of psychological study, she would have repudiated Freud's definition of the subconscious mind. She would have surely endorsed Lawrence's idea that "the true unconscious is the well-head, the fountain of real motivity" (Lawrence, 2004, p. 9). Like Lawrence, Bronte believed that the unconscious mind is a source of creativity and the origin of a person's individuality. In her novel, Wuthering Heights, Catherine's affinity with Heathcliff is so much more than a feeling of empathy and closeness. Several times throughout the novel, she identifies herself directly with him - "Nelly, I am Heathcliff! He's always, always in my mind: not as a pleasure, any more than I am always a pleasure to myself, but as my own being" (Brontë, 2009, p. 71). The word "being" is graphic in its meaning. Originating in Middle English around 1240, it is paradoxically symbolic that a word, meaning life and vitality, could appear in a period traditionally associated with darkness, chaos and gloom.

With the advent of the Renaissance at the beginning of the $14^{\text {th }}$ century, the word "being" underwent a morphological shift from a word meaning "life" to a mechanical label meaning "to exist". Defined in the Oxford English Dictionary as "to have objective reality or being", this morphological shift in meaning reflected the preoccupations of the age, and "objective" is the operative word. Eliminating any association with subjective feeling, this new definition, to quote the words of Dickens (1848) in Dombey and Son, reflected "How dreadfully we have degenerated" (p. 407). Emily Bronte, by linking the word "being" with her gothic imagery, Bronte reverts to its original meaning, with all its connotations of spontaneity and naturalness. She believed that conventional society, with its penchant for generalization and ordered institutions, stifled individual growth and repressed true feeling. Her heroine, Catherine Earnshaw, feels suffocated by refined society. In marrying Linton, she realises that she has denied her sense of being - her sense of self. In a dramatic outburst to Nelly, she declares "I'm sure I should be myself were I once 
among the heather on those hills" (Brontë, 2009, p. 116). The conjunction, "once", is suggestive of both of, an immediacy, and a past time when, as a child, she roamed on the moors "half savage and hardy, and free" (p. 116).

Emily Bronte, then, the gothic world is synonymous with life. In a reversal of literary convention, where the gothic is terrifying and destructive, her gothic world rejuvenates her characters and makes them strong. Catherine remembers, as a child on the Moors, with Heathcliff by her side, "laughing at injuries" which, as an adult, are "maddening" to her. She recognizes that the conventional society, in which she finds herself, has ultimately destroyed her ability to live. More than 70 years later, Lawrence develops these ideas into a full-blown metaphysic. He, too, recognized the unadulterated thrill for life, associated with childhood, and deplored the dehumanising nature of modern society, whose only aim was to force man into "a consciousness of all the laughing, and the never-ceasing murmur of pain and sorrow that comes from the terrible multitudes of brothers" (Lawrence, 2002, p. 40). It is clear, then, that Emily Bronte's gothic world is a fictional representation of her own childhood environment. It is symbolic that her sister Charlotte, in the preface to the second edition of the book, should call her a "nursling of the moors". The Moors offered her an umbilical cord to survival and it was a world in which she felt safe and alive. There is no wonder, then, that her heroine, Catherine Earnshaw, should feel the same way.

Emily Bronte's preoccupation with death, as portrayed in her novel, "Wuthering Heights", is a stark indication of her rejection of society. Her discontent and frustration echoed through the ages to become an expression of the human condition. Lawrence (2018) wrote, in his novel, Women in love, "But better die than live mechanically a life that is a repetition of repetitions" ( $p$. 219). The heroine of Wuthering Heights, Catherine Earnshaw, expresses a similar sentiment. The world of Thrushcross Grange is, for her, a "shattered prison" (Brontë, 2009, p. 143). which suffocates and encloses her. She rejects it outright, yearning for death, which will release her into the "glorious world", associated in her mind with the freedom and untamed exhilaration of the Moors. As such, her affinity is with Heathcliff and she declares to Nelly "I cannot live without my life! I cannot live without my soul!" (p. 148) .The imagery is pure gothic. However, unlike conventional gothic fiction, Bronte's heroine is running from a deathlike existence, within the confines of traditional society, towards actual death, which will offer her an eternal life of freedom and the anticipation of a union with her true self. She recognizes that, as a strong and independent woman, the society in which she lives will never sanction the fulfilment of her inner being, epitomised by a union with Heathcliff.

Paradoxically, despite being a parson's daughter, Emily Bronte's view of the afterlife, as presented in her novel, Wuthering Heights, is purely gothic. Once more, through a reversal of literary convention, the gothic world, inhabited by the ghostly spectres of Heathcliff and Catherine, comes to represent freedom and escape from the constraints of repressive social and religious norms. The "glorious world", to which Catherine refers, has nothing to do with the paradise of conventional religion. She is eagerly awaiting death so that she can become her true self once more free to roam unfettered on the wild and eerie Moors. For Bronte, death comes to represent a welcome release from the constraints of a repressive society. Unlike traditional gothic fiction, which used death to increase the tension and psychological terror of the plot, Emily Bronte's 
picture of death as a release, and as a means of rebirth, is innovative, anticipating Lawrence's spiritual creed. He also saw death as a means of embracing life, once famously saying that "The near touch of death may be a release into life" (Lawrence, 2013, p.320). By dying, Catherine is able to embrace her true identity, which is intrinsically linked with her love for Heathcliff, a union which society would never condone.

\title{
Conclusion
}

In writing her novel, Wuthering Heights, Emily Bronte aimed to present an image of the female personality, trying to thrive under the restrictions imposed on it by the conventions of the time. Catherine, rather than Heathcliff, is the central character. The novel explores her attempt to reconcile the two facets of her personality: refined feeling, as epitomised through her marriage to the socially acceptable Linton, and her wilder, instinctive nature, nurtured through her childhood relationship with Heathcliff.

The author skilfully uses the gothic mode to achieve her aim. Traditionally, gothic novels create phantasmagorical worlds which entertain but alienate the reader. Bronte innovatively grounded her gothic elements firmly in reality in an attempt, not only to attract the reader's sympathy, but also to underline the veracity of her ideas. These wilder, instinctive impulses are really part of the human personality, and instead of trying to eliminate them, society should attempt to assimilate them.

This article shows how Emily Bronte reversed gothic convention to create a world of passion so vital, and so real, forcing the reader to feel with her. Bronte exploits all the elements of the gothic novel to perfection but she is innovative in her technique, creating a world of gothic reality whose message is still relevant today. She used the gothic to indicate that she was exploring facets of the personality that were unacceptable to society, but she grounded them in reality to show that they really did exist.

Emily Bronte's use of the gothic mode was an attempt, then, to capture the real essence of life. Her innate understanding of human nature anticipated the metaphysical theories of D.H. Lawrence, who recognized that human beings are governed by powerful, primal instincts and that human relationships are irrational. Hampered by her sex, and the repressive forces of the age, Bronte, unlike Lawrence, did not have the courage to overtly flout convention. The gothic mode, then, offered her the subterfuge, not only to confront her own social demons, but also to safely criticize outdated, and to her mind, antiquated institutions. Her message is powerful and universal, furthering the premise that if she had lived, she would have developed her ideas into a full-blown philosophy, rivalling that of many of the greatest writers of the twentieth century.

\begin{abstract}
About the Author:
Roumaissa MOUSSAOUI has taught English literature for three years at the University of Ali Louinci , Blida2. Dr. Moussaoui was also an English language teacher in high school for five years. She has written a PhD thesis in English literature entitled; Mapping D.H.Lawrence's Apocalypse. At the present time, her research focus is on nineteenth and early twentieth century English literature.
\end{abstract}

Arab World English Journal for Translation \& Literary Studies 
AWEJ for Translation \& Literary Studies Volume, 5 Number 3. August 2021

Gothic Reality: A Study of Emily Bronte's Wuthering Heights

Moussaoui

\section{References}

Axelrod, M. (1999). The Poetics of Climate in Brontë's Wuthering Heights. In The Poetics of Novels (pp. 55-76). Palgrave Macmillan, London.

Botting, F. (1996). Gothic. London: Routledge.

Brontë, E. (2009). Wuthering Heights. Penguin Classics Deluxe Edition.

Brontë, C., Brontë, E., \& Brontë, A. (2005). Selected works of the Brontë sisters. Wordsworth Editions.

Brontë, E., \& Hatfield, C. W. (1995). The complete poems of Emily Jane Brontë. New York: Columbia University Press.

Clery, E. (2010). Horace Walpole, the Strawberry Hill Press, and the Emergence of the Gothic Genre. ars \& humanitas, 4(1-2), 93-111.

Conger, S. M. (1983). The Reconstruction of the Gothic Feminine Ideal in Emily Brontë's Wuthering Heights. The Female Gothic, 91-106.

Dickens, C. (1848). Dombey and son (Vol. 1). Createspace Independent Publishing Platform.

Disraeli, I., \& Disraeli, B. (1868). The calamities and quarrels of authors: With some inquiries respecting their moral and literary characters, and memoirs for our literary history. New York: W.J. Widdleton.

Fu, H. (2013). An Interpretation of Emily Bronte's Gothic Complex in Wuthering Heights. Studies in Literature and Language, 6(3), 53-59.

Gold, L. (1985). Catherine Earnshaw: Mother and Daughter. The English Journal, 74(3), 68-73.

Homans, M. (1978). Repression and sublimation of nature in Wuthering Heights. Publications of the Modern Language Association of America, 9-19.

Horner, A. (2010).Women, Power and Conflict: The Gothic heroine and "Chocolate-box Gothic".

Caliban. French Journal of English Studies, URL:

https://journals.openedition.org/caliban/2218

Lawrence, D. H. (2013). Delphi Complete Works of DH Lawrence (Illustrated) (Vol. 3). Delphi Classics.

Lawrence, D. H., Squires, M. (1994). Lady Chatterley's lover: A propos of "Lady Chatterley's lover". London: Penguin Books.

Lawrence, D. H. (2004). Psychoanalysis and the Unconscious' and 'Fantasia of the Unconscious (Vol. 31). Cambridge University Press.

Lawrence, D. H. (2002). The letters of DH Lawrence (Vol. 8). Cambridge University Press.

Lawrence, D. H. (1987). Women in love (Vol. 9). Cambridge University Press.

Mohammed, A. R. M. (2016). The Influence of Gothic Elements on the Characters of the Novel Wuthering Heights (Doctoral dissertation, Sudan University of Science and Technology). URL: http://repository.sustech.edu/handle/123456789/13968

Oda, Y. (2010). Emily Brontë and the Gothic: Female Characters in Wuthering Heights. Revue LISA/LISA e-journal. Littératures, Histoire des Idées, Images, Sociétés du Monde Anglophone-Literature, History of Ideas, Images and Societies of the English-speaking World, 1-19. URL: http://journals.openedition.org/lisa/3496

Qiao, W. (2019). How is Wuthering Heights a Gothic Novel. International Journal of English and Literature, 4, 1578-1583. URL: https://dx.doi.org/10.22161/ijels.45.48

Walpole, H. (1791). The castle of Otranto: A Gothic story. Parma: printed by Bodoni, for J. Edwards, Bookseller of London.

Arab World English Journal for Translation \& Literary Studies 